\title{
Working
}

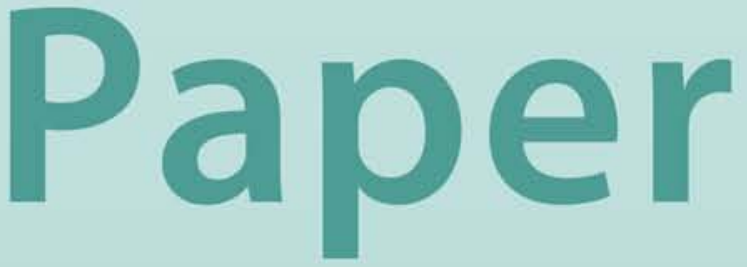




\section{Is One Watchdog Better Than Three? International Experience with Integrated Financial Sector Supervision} Martin Čihák and Richard Podpiera 


\title{
IMF Working Paper
}

Monetary and Financial Systems Department

\section{Is One Watchdog Better Than Three? International Experience with Integrated Financial Sector Supervision}

\author{
Prepared by Martin Čihák and Richard Podpiera ${ }^{1}$ \\ Authorized for distribution by Mark W. Swinburne
}

March 2006

\begin{abstract}
This Working Paper should not be reported as representing the views of the IMF.

The views expressed in this Working Paper are those of the author(s) and do not necessarily represent those of the IMF or IMF policy. Working Papers describe research in progress by the author(s) and are published to elicit comments and to further debate.

Over the past two decades, there has been a clear trend toward integrating the regulation and supervision of banks, nonbank financial institutions, and securities markets. This paper reviews the international experience with integrated supervision. We survey the theoretical arguments for and against the integrated supervisory model, and use data on compliance with international standards to assess the validity of some of these arguments. We find that (i) full integration is associated with higher quality of supervision in insurance and securities and greater consistency of supervision across sectors, after controlling for the level of development; and (ii) fully integrated supervision is not associated with a significant reduction in supervisory staff.
\end{abstract}

JEL Classification Numbers: G18, G28, K20, L50

Keywords: financial sector, financial services regulation, prudential supervision, supervisory agencies, integrated supervision

Author(s) E-Mail Address: mcihak@imf.org and rpodpiera@imf.org

\footnotetext{
${ }^{1}$ The authors would like to thank—without implicating—Ashok Bhatia, Ana Carvajal, Udaibir S. Das, Jennifer Elliott, Michaela Erbenová, Socorro Heysen, Michal Mejstřík, Mark O’Brien, Marc Quintyn, Klaus Schaeck, Mark Swinburne, Judit Vadasz, and participants in seminars at the International Monetary Fund and the Czech Economic Association for useful comments.
} 


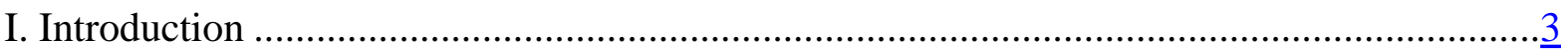

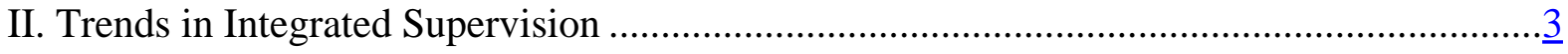

III. Review of Literature on Integrated Financial Supervision .......................................... $\underline{8}$

A. Possible Benefits of Integrated Supervision .....................................................

B. Potential Disadvantages of Integrated Supervision..........................................

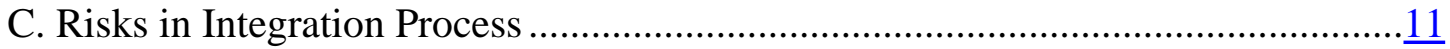

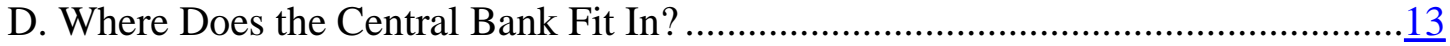

E. Why Do Countries Integrate Their Supervisory Structures?................................15

IV. Analysis of International Experience with Integrated Supervision ...............................16

A. Does Integration Mean a Higher Quality of Supervision?................................... $\frac{16}{23}$

B. Does Integration Mean More Consistent Supervision Across Sectors?................... 23

C. Does Integration Help Reduce Resource Costs? ...................................................

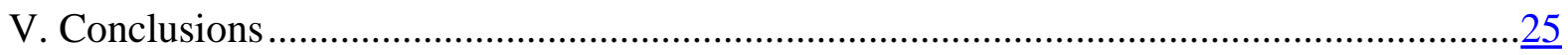

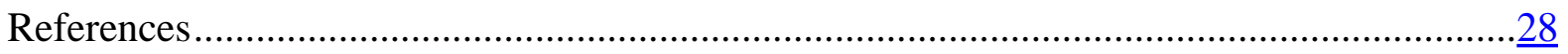

Box

1. Integrated Supervision and Financial System Soundness...............................................21

Tables

1. General Structure of Financial Sector Regulation and Supervision ................................... $\underline{5}$

2. Economies with Single, Semi-Integrated, and Sectoral Prudential Supervisory Agencies,

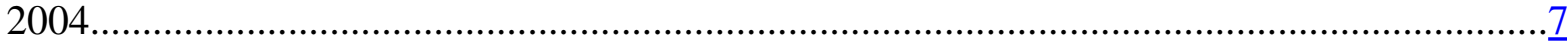

3. Summary of Pros and Cons of Integrating Financial Sector Supervision ........................13

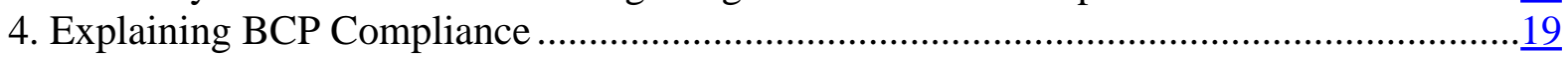

5. Financial Standards and Their Four Main Components ..............................................20

6. Explaining BCP, ICP and IOSCO Compliance by Main Components .............................22

7. Explaining Variability in Compliance with International Standards .................................23

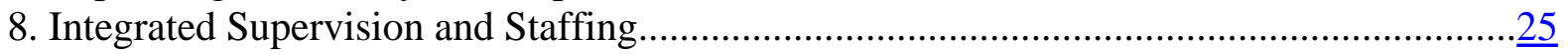

Figures

1. Number of Integrated Supervisory Agencies, 1985-2004 ….........................................

2. Regional Distribution of Integrated Supervisory Agencies, 2004 ...................................

3. BCP Compliance and Overall Regulatory Environment .............................................18

4. Supervisory Staffing in Countries with Integrated Supervision, 1996-2003 .................... 25 


\section{INTRODUCTION}

The last twenty years have been characterized by increasing integration of the banking, securities and insurance markets, as well as their respective products and instruments. Largely in response to the integration in the markets, there was a substantial shift from the traditional sector-by-sector approach to supervision toward integrated financial supervision.

This paper presents the first comprehensive, cross-country analysis of the emerging experience with integrated financial supervision. We survey the theoretical arguments for and against the integrated supervisory model and use empirical data to assess the validity of some of these arguments. In particular, we analyze how the quality of supervision (measured by compliance with international standards and codes) in countries with fully integrated supervisors compares with that in other countries. We also use data on staffing to assess any potential cost savings associated with fully integrated supervision.

So, is one watchdog better than two, three, or more? Although there are a number of theoretical arguments for and against the integrated model, our empirical results suggest that (i) integrated supervision is generally associated with higher quality and consistency of supervision across supervised institutions, even though a large part of the difference is explained by other variables, mainly income level; and (ii) integrated supervision is not associated with a significant reduction in supervisory staff.

The structure of the paper is as follows. Section II reviews the trends in integration of supervision. Section III surveys the theoretical arguments for and against integration. Section IV analyzes some of these arguments using the available empirical experience, and Section V concludes.

\section{TRENDS IN INTEGRATED SUPERVISION}

One of the most notable developments in the financial landscape in many countries has been the ongoing cross-sector and cross-border consolidation of financial institutions, which has led to a blurring of distinctions between financial sectors and national financial markets (e.g., Group of Ten, 2001; Zalm, 2005). For example, the number of conglomerates in the top 500 financial institutions worldwide has increased from 42 percent to 60 percent between 1995 and 2000 (De Nicoló and others, 2003). ${ }^{2}$

Partly in response to the increased consolidation in the financial sectors, the number of fully integrated supervisory agencies has grown rapidly in the last two decades (Figure 1). ${ }^{3}$ The

\footnotetext{
${ }^{2}$ The classification of conglomerates versus nonconglomerates was based on information on their major lines of business and/or main activities (for example banking, insurance, and securities).

${ }^{3}$ Here, we consider any supervisory agency that is responsible for prudential supervision of banking, insurance, and securities markets to be "fully integrated." We explore the issue of different models, functions, and definitions later in this section.
} 
first countries to embark on integrated supervision were Singapore in 1982 and Norway in 1986. In the following years, integrated supervisors were established in other Nordic countries and then elsewhere in Europe. Outside Europe, a unified agency was established in Australia, The Republic of Korea, Japan, and a number of other countries. As of the end of 2004, there were 29 fully integrated supervisory agencies worldwide, of which about half were in Europe (Figure 2).

Figure 1. Number of Integrated Supervisory Agencies, 1985-2004

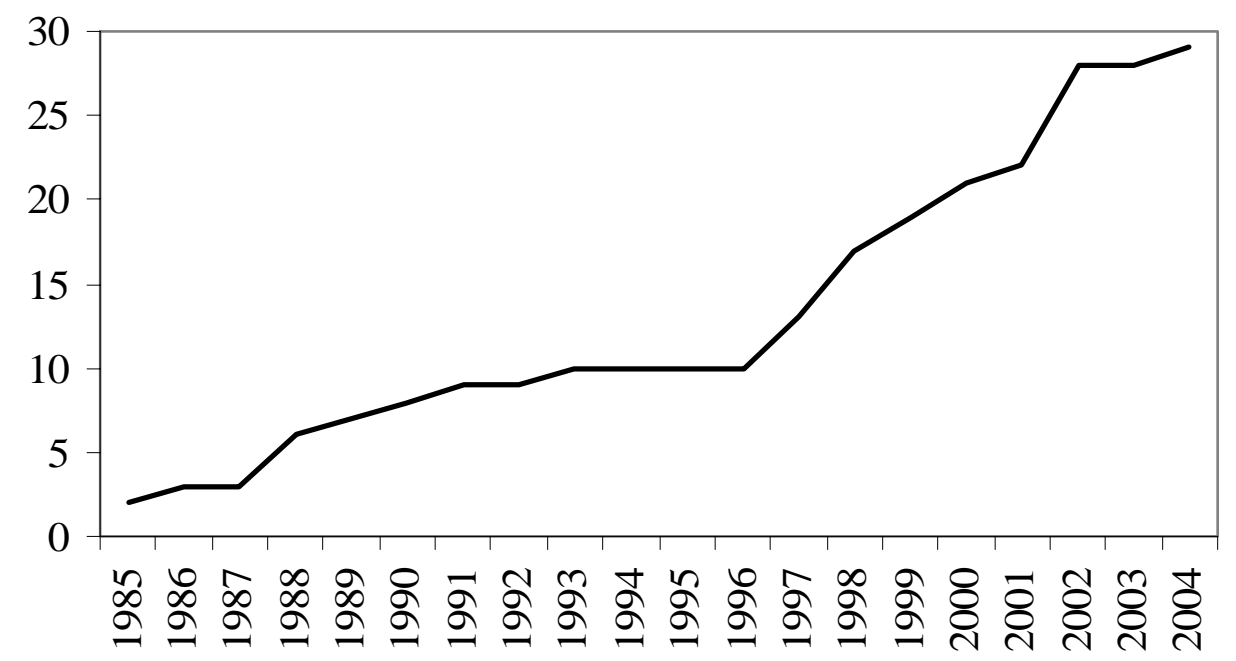

Source: Authors’ calculations, based on data in Central Banking Publications (2004).

Figure 2. Regional Distribution of Integrated Supervisory Agencies, 2004

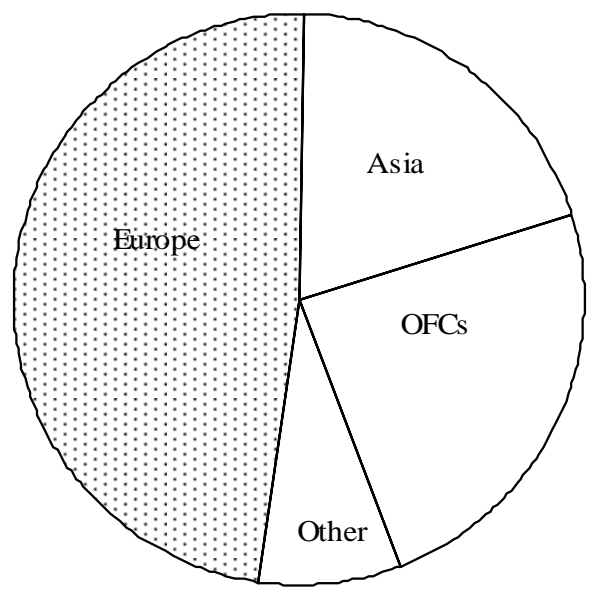

Source: Authors, based on data in Central Banking Publications (2004). 
Prudential supervision is part of the broader framework for financial sector regulation and supervision. The framework consists of macroprudential surveillance, microprudential supervision, consumer protection, and competition policy, each of which responds to one type of market failure (Table 1). In most countries, macroprudential surveillance is carried out by a central bank, and competition issues are handled by a separate agency regulating competition in general. The focus of this paper is on the middle (shaded) part of the table, i.e., microprudential supervision and consumer protection.

Table 1. General Structure of Financial Sector Regulation and Supervision

\begin{tabular}{|c|c|c|c|c|c|}
\hline \multicolumn{2}{|c|}{ Type of Market Failure } & Systemic Instability & $\begin{array}{l}\text { Asymmetric } \\
\text { Information }\end{array}$ & $\begin{array}{c}\text { Market } \\
\text { Misconduct }\end{array}$ & $\begin{array}{c}\text { Anticompetitive } \\
\text { Behavior }\end{array}$ \\
\hline \multicolumn{2}{|c|}{ Regulatory area } & $\begin{array}{c}\text { Macroprudential } \\
\text { surveillance/financi } \\
\text { al stability }\end{array}$ & $\begin{array}{l}\text { Microprudential } \\
\text { supervision/indivi- } \\
\text { dual institutions }\end{array}$ & $\begin{array}{c}\text { Business } \\
\text { supervision/con- } \\
\text { sumer protection }\end{array}$ & Competition \\
\hline \multirow{4}{*}{ 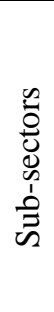 } & Banks & \multirow{4}{*}{$\begin{array}{l}\text { Central bank, } \\
\text { monetary authority }\end{array}$} & One 1/ & One & \multirow{4}{*}{$\begin{array}{l}\text { Separate agency } \\
\text { responsible for } \\
\text { competition in } \\
\text { general }\end{array}$} \\
\hline & Insurance companies & & or & or & \\
\hline & Capital market firms & & more & more & \\
\hline & Other financial firms & & agencies & agencies & \\
\hline
\end{tabular}

Source: Authors, based loosely on Kremers, Schoenmaker, and Wierts (2003) and Carmichael, Heming, and Llewellyn (2004).

$1 /$ Deposit insurers can have an important role in banking supervision, no matter which regulatory model is applied across sectors.

We define a fully integrated supervisory agency as an agency that is in charge of (micro)prudential supervision of at least the three main segments of most financial sectorsbanking, insurance, and securities markets. Such agency may or may not be in charge of consumer protection. Under this definition, a framework where one supervisory agency is in charge of all prudential supervision in the three main sectors, and another one is responsible for market conduct, consumer protection, and corporate governance (so called "twin peaks" framework) qualifies as integrated supervision. ${ }^{4}$ In contrast, partly integrated supervisory agencies (which are in charge of prudentially supervising two of the three segments), and sectoral supervisors (which supervise only one segment), do not qualify as integrated supervisors. In theory, there are alternatives to full integration, for instance, creation of a unified oversight board or sharing of support services among agencies, but these are not widespread and we do not address them in this paper.

\footnotetext{
${ }^{4}$ The Australian Prudential Regulation Authority (APRA) and the Australian Securities and Investments Commission (ASIC) are an example of such a "twin peaks" supervisory structure.
} 
Despite the trend toward fully integrated supervision, there is still a wide range of models for supervisory structure that have been adopted in various countries (Table 2). The framework for organizing supervision functions is along sectoral lines (multiple supervisors), is integrated for two sectors regardless of the objectives of supervision, or is integrated across all sectors into one agency. National differences reflect a multitude of factors: historic evolution, structure of the financial system, political structure and traditions, and size of the country and financial sector. The fully integrated supervisory model can be found in a wide range of financial systems, from very small (e.g., some of the offshore financial systems) to large and complex (e.g., United Kingdom and Japan), from very concentrated (e.g., Estonia) to relatively dispersed (e.g., United Kingdom), and from countries with a systemic banking crisis prior to integration (e.g., Norway) to countries with no recent systemic banking crisis.

Our paper focuses on domestic supervisory integration, but the importance of cross-border integration will also continue to increase as the cross-border linkages among financial systems continue to grow rapidly. The recent growth of cross-border integration of supervision is evidenced for example by increasing numbers of memoranda of understanding (MOUs) among supervisory agencies from different countries. ${ }^{5}$ There is an ongoing-though so far only theoretical-discussion on a Europe-wide supervisor (e.g., Kremers, Schoenmaker, and Wierts, 2001). Australia and New Zealand have been working on implementing an enhanced "home-host" model of supervision for their highly integrated banking systems (Reserve Bank of New Zealand, 2004).

\footnotetext{
${ }^{5}$ For example, the number of MOUs with foreign supervisors signed by Bank of England and the Financial Services Authority in the United Kingdom increased from 1 in 1995 to 20 in 2005; for the Czech National Bank, the number of cross-border MOUs increased from 0 in 2000 to 8 in 2005.
} 
Table 2. Economies with Single, Semi-Integrated, and Sectoral Prudential Supervisory Agencies, 2004 1/

\begin{tabular}{|c|c|c|c|c|c|c|}
\hline \multirow{2}{*}{\multicolumn{2}{|c|}{$\begin{array}{l}\text { Single Prudential Supervisor for the } \\
\text { Financial System (year of establishment) }\end{array}$}} & \multicolumn{3}{|c|}{ Agency Supervising Two Types of Financial Intermediaries } & \multirow{2}{*}{\multicolumn{2}{|c|}{$\begin{array}{l}\text { Multiple Sectoral Supervisors } \\
\text { (at least one for banks, one for securities firms, } \\
\text { and one for insurers) }\end{array}$}} \\
\hline & & \multirow{2}{*}{$\begin{array}{l}\text { Banks and securities } \\
\quad \text { firms }\end{array}$} & \multirow{2}{*}{$\begin{array}{l}\text { Banks and insurers } \\
\text { Canada } \\
\text { Colombia } \\
\text { Ecuador } \\
\text { El Salvador } \\
\text { Guatemala } \\
\text { Malaysia* } \\
\text { Peru } \\
\text { Venezuela, Rep. } \\
\text { Bolivariana de }\end{array}$} & $\begin{array}{l}\begin{array}{l}\text { Securities firms and } \\
\text { insurers }\end{array} \\
\text { Bolivia } \\
\text { Bulgaria* } \\
\text { Chile } \\
\text { Jamaica* } \\
\text { Mauritius* } \\
\text { Slovak Republic* 2/ } \\
\text { Ukraine* }\end{array}$ & & \\
\hline $\begin{array}{l}\text { Australia (1998) } \\
\text { Austria (2002) } \\
\text { Bahrain* (2002) } \\
\text { Belgium (2004) } \\
\text { Bermuda* (2002) } \\
\text { Cayman Islands* } \\
\text { (1997) } \\
\text { Denmark (1988) } \\
\text { Estonia (1999) } \\
\text { Germany (2002) } \\
\text { Gibraltar (1989) } \\
\text { Guernsey (1988) } \\
\text { Hungary (2000) } \\
\text { Iceland (1988) } \\
\text { Ireland* (2002) }\end{array}$ & $\begin{array}{l}\text { Japan (2001) } \\
\text { Kazakhstan* (1998) } \\
\text { Korea, Rep. (1997) } \\
\text { Latvia (1998) } \\
\text { Maldives*(1998) } \\
\text { Malta* (2002) } \\
\text { Netherlands*(2004) } \\
\text { Nicaragua * (1999) } \\
\text { Norway (1986) } \\
\text { Singapore* (1984) } \\
\text { South Africa * (1990) } \\
\text { Sweden (1991) } \\
\text { United Arab Emirates* } \\
\text { (2000) } \\
\text { United Kingdom (1997) } \\
\text { Uruguay (1993) }\end{array}$ & & & $\begin{array}{l}\text { Bolivia } \\
\text { Bulgaria* } \\
\text { Chile } \\
\text { Jamaica* } \\
\text { Mauritius* } \\
\text { Slovak Republic*2/ } \\
\text { Ukraine* }\end{array}$ & $\begin{array}{l}\text { Albania* } \\
\text { Argentina* } \\
\text { Bahamas, The* } \\
\text { Barbados* } \\
\text { Botswana* } \\
\text { Brazil* } \\
\text { China } \\
\text { Croatia* } \\
\text { Cyprus* } \\
\text { Czech Republic 2/ } \\
\text { Dominican Rep* } \\
\text { Egypt* } \\
\text { France* } \\
\text { Greece* } \\
\text { Hong Kong SAR* } \\
\text { India* } \\
\text { Indonesia* } \\
\text { Israel* }\end{array}$ & $\begin{array}{l}\text { Italy* } \\
\text { Jordan* } \\
\text { Lithuania* } \\
\text { New Zealand* } \\
\text { Panama } \\
\text { Philippines* } \\
\text { Poland* } \\
\text { Portugal* } \\
\text { Russia* } \\
\text { Slovenia* } \\
\text { Sri Lanka* } \\
\text { Spain* } \\
\text { Thailand* } \\
\text { Tunisia* } \\
\text { Turkey } \\
\text { Uganda* } \\
\text { United States* }\end{array}$ \\
\hline & & & of all countries in the & sampie (percent) & & \\
\hline & 3 & 6 & 11 & 9 & & 41 \\
\hline
\end{tabular}

Sources: Based on data in Central Banking Publications (2004), and on websites of supervisory agencies.

* Banking supervision is conducted by the central bank.

1/ The table focuses on prudential supervision, not on business supervision (which can be carried out by the same agencies or by separate agencies, even in the integrated model). Also, we do not consider deposit insurers here, even though they play an important role in banking supervision in a number of countries and can do so under any regulatory model.

2/ The authorities announced plans to integrate prudential supervision in their central banks in 2006. 


\section{REVIEW OF LITERATURE ON INTEGRATED FINANCIAL SUPERVISION}

This section reviews the key arguments for and against integrating financial sector supervision identified in the literature, mostly following Abrams and Taylor (2000). ${ }^{6}$ It also reviews the work that analyzed reasons why countries decide for integrated supervision.

The theoretical literature on the subject notes that the structure of regulation and supervision is only one aspect that affects its effectiveness and efficiency (e.g., Carmichael, Fleming, and Lewellyn, 2004). Key prerequisites, some of which are linked to the organization of the supervisor, include clear objectives, independence and accountability, adequate resources, effective enforcement powers, comprehensiveness of regulation, and cost efficiency. ${ }^{7}$ However, it would be too simplistic to consider the organization of regulation and supervision to be only a second-order problem as it may often have a strong impact on the degree to which the key pre-requisites are satisfied.

The literature generally concludes that the question of the most appropriate structure for regulation and supervision is to a large extent a practical one and the answer depends on an interaction of a number of factors that, moreover, evolve over time. Therefore, there is no strong theoretical argument for any particular organization of supervision, there are only potential advantages and disadvantages of various setups, the importance of which depends on the conditions in place in a given jurisdiction.

\section{A. Possible Benefits of Integrated Supervision}

The most important arguments for unified supervision are related to efficiency, effectiveness, and issues stemming from the creation of financial conglomerates. Merging multiple supervisors should increase efficiency, even if only by eliminating duplicated support functions, not to mention broader synergies. Blurring of demarcation lines among financial sectors and the creation of conglomerates in many industrialized countries have created an added incentive to unify supervision to avoid regulatory gaps and to ensure competitive neutrality.

The rise of financial conglomerates has also raised the issue of how to supervise them efficiently and effectively. ${ }^{8}$ Financial conglomerates cover a range of financial services for

\footnotetext{
${ }^{6}$ The literature reviewed here is theoretical in the sense that it provides theoretical arguments rather than an empirical assessment. Formal theoretical models of supervision (e.g., Dewatripont and Tirole, 1994) focus on banking supervision and say little on supervising nonbank financial institutions, which is an area for future research. Also, see Kahn and Santos (2005) for a discussion on allocating the lender of last resort, deposit insurance, and supervision responsibilities within banking supervision.

${ }^{7}$ Abrams and Taylor (2000) provide a more detailed overview of the key preconditions. Das and Quintyn (2002) examine the general role and country experience with regulatory governance, which includes independence, accountability, transparency, and integrity, and Huepkes, Quintyn, and Taylor (2005) explore the accountability aspect in detail. Also, Das, Quintyn, and Chenard (2004) analyze whether regulatory governance matters for financial system stability.

${ }^{8}$ For more information about financial sector developments and conglomerates, see for instance Group of Ten (2001) and De Nicolo and others (2003).
} 
which supervision has been typically fragmented and this has raised concerns about the ability of supervisors to assess the overall risk the conglomerate is taking. But besides the need to take a consolidated view and assess group-wide risks that may not exist at a lower level, the existence of financial conglomerates has also increased the importance of having a regulatory and supervisory framework that is consistent and free of gaps. While supervisors try to make companies create firewalls among their different businesses, the effectiveness of such firewalls could be low in case of financial problems and they certainly do not protect against all forms of regulatory arbitrage. Furthermore, in crisis management, supervisors need to be able to respond on a conglomerate-wide basis even if problems affect, initially, only one part of the conglomerate.

While some or perhaps all of the issues outlined above could be resolved by close coordination and cooperation of sectoral supervisors, an integrated supervisor is likely to be in a much better position to address them. In particular, coordination and exchange of information may be smoother within one institution, as does the effort to close any existing regulatory gaps. For the conglomerates, an integrated supervisor may be able to minimize the burden of supervision as well, by minimizing any overlaps and duplication, and simplify the decision making process.

In terms of competitive neutrality, an integrated supervisor may be better able to ensure that similar financial products receive comparable regulatory treatment, leveling the playing field for all financial sector participants. This is particularly important given that the differences among institutions and products have become blurred to some extent in recent years. Differences in regulation may give some financial services providers an unfair advantage, but also could encourage regulatory arbitrage as conglomerates would place particular financial products into the part of the conglomerate where the oversight or costs are the lowest. Sectoral supervisors could be tempted to compete for “clients” by relaxing supervisory requirements instead of trying to harmonize supervision across sectors. ${ }^{9}$

An integrated financial supervisor is also likely to be more flexible. A single institution may deal more effectively with possible turf wars that could lower the effectiveness of a supervisory system based on sectoral supervisors. An integrated supervisor may be also better placed to respond more promptly and effectively to the emergence of new products and services, which is important not only for financial innovation in industrialized countries, but also for financial systems in emerging and developing economies, which undergo substantial structural changes.

Economies of scale should lead to greater efficiency of operations of an integrated supervisor. Shared infrastructure, administrative and support functions can directly reduce costs. A large organization should also allow greater specialization of staff and acquisition of technologies that may be too costly for each supervisor separately. In the actual supervisory

\footnotetext{
${ }^{9}$ Complete competitive neutrality may not be the ultimate goal of a supervisory system, because the optimal intensity of supervision of similar products is likely to depend on the type of institution involved —as long as different types of institutions pose different degree of systemic risk.
} 
work, unified data collection can help create a more efficient reporting system and unnecessary duplication of research and data collection could be avoided. ${ }^{10}$

Economies of scale extend to staffing as well. A larger organization may be better placed to attract, train, and retain professional staff. A human resources policy could be easier to develop in a large organization, which could also offer more a diverse and interesting career path for its staff. Integration should also make it easier to share and use effectively specialized knowledge across supervised sectors.

Integrating supervision may improve accountability. When there is one supervisor, it is very clear who bears the responsibility for supervision, thus eliminating the possibility of "blame games" among sectoral supervisors. However, the objectives of the integrated supervisor must be well defined.

Individual country cases suggest that for economies with small financial sectors, the economies of scale from establishing an integrated agency outweigh the costs of moving to such a model. A case can also be made for consolidated supervision in a system dominated by banks, with little role for capital markets or a highly integrated financial sector.

\section{B. Potential Disadvantages of Integrated Supervision}

There are also several arguments against the integrated supervisor model. First, if the objectives of the integrated supervisor are not clearly specified, an integrated supervisor may be less effective than sectoral supervisors. Second, the economies of scope (synergies) may be difficult to achieve as long as the regulations across banking, insurance, and securities are not harmonized. Third, there may even be some diseconomies of scale. Fourth, an integrated supervisor may extend moral hazard problems across the whole financial sector.

The range of objectives of an integrated supervisor may be rather wide, from maintaining systemic stability in the banking sector to protecting customers of insurance companies or pension funds. Therefore, if the objectives are not clearly specified and communicated to all stakeholders, the supervisor may not be able to differentiate among different types of institutions, accountability of the supervisor may be lower, and the supervisor may struggle in the event of conflict between different objectives.

If sectoral supervisors are simply put under one roof, without substantial organizational changes and changes in the regulation of individual sectors, the synergies will be likely small. Creating a truly single agency without substantial differences in style, culture, and, indeed, quality of supervision, is a demanding managerial task. Furthermore, complete integration may not be possible, as the types of supervised businesses and the issues under consideration may be too diverse-e.g., from credit risk in banking to consumer protection in the pension funds industry.

\footnotetext{
${ }^{10}$ Cost savings could be also achieved if sectoral supervisors agreed to share support services.
} 
The integrated supervisor could become too large an organization to be managed effectively, leading to diseconomies of scale. Very large organizations are likely to become more bureaucratic and inflexible, compared to smaller sectoral supervisors. If the operations become too broad-based, managers may not be able to understand the full range of responsibilities of the organization, lowering its efficiency and effectiveness. This issue, however, is likely to be very much country-specific, as an integrated supervisor may be a smaller organization than sectoral supervisors in large countries.

Moral hazard is another potential problem. Financial market participants may believe that all creditors of all institutions supervised by an integrated supervisor will receive the same protection. For instance, the creditors of other financial institutions may expect—and demand through a political process in case of financial problems - that they will be given the same protection as the depositors in banks. This could implicitly extend the banking safety net to other parts of the financial sector for which such safety net may not be appropriate. While this is an informational problem and a clear communication strategy by the supervisor would alleviate it partly, it is unlikely to be fully resolved unless and until the supervisor acts exactly in line with the pre-announced rules in specific cases of financial failures.

\section{Risks in Integration Process}

It is not only the final structure of supervision, the integration process itself may bring substantial risks. ${ }^{11}$ There may be a risk that: (i) some politicians will use the fact that the supervisory structure is open for discussion to push through the creation of a unified supervisor quickly no matter whether it is optimal; (ii) the change process will reopen issues in regulation and supervision and that their effectiveness will be diminished by special interests in the financial sector; (iii) integration will lead to loss of key staff and the effectiveness of regulation will be therefore lowered; and (iv) the technical process of integration will be mismanaged and the supervisor will not pay full attention to developments in the financial sector.

Once the creation of an integrated supervisor is open for discussion, the political process may lead to its creation no matter whether such model is optimal under a given country's circumstances or not. Some politicians who would see an opportunity to increase their influence in regulation and supervision may be tempted to push changes quickly, without proper public discussion, before the balance of power shifts against them. A rushed proposal may then lead to creation of an agency with unclear objectives, low degree of independence, or other serious flaws.

The integration process requires creation of new legislation, but this may be an opportunity for special interests in the financial sector to capture the process and lower the effectiveness of regulation and supervision. Major issues that were likely settled under the existing system

\footnotetext{
${ }^{11}$ In cases where the unified supervision resulted also in merging prudential supervision with customer protection issues, the integration involved a drastic reduction of supervisory agencies (e.g., in the United Kingdom, the creation of the Financial Services Authority meant that the number of financial sector supervisory agencies declined from ten to one).
} 
of sectoral supervisors may now be reopened and the resulting legislation supporting the integrated supervisor may be weakened relative to the previous situation. Relevant issues may concern the scope of activities of the financial sector firms, powers of the supervisor, exemptions for regulatory requirement, etc. One way to minimize this potential problem is to leave the sectoral legislation largely intact and approve only a simple law enabling the creation of the integrated supervisor. However, while such approach minimizes the risk that the legislative process will be captured by special interests, it also lowers the potential benefits of harmonization of the legislation in different sectors.

The integration process may lead to a loss of key staff or a very high level of turnover. Any major change brings uncertainty, and, if compounded by less than skillful management, delays or even the prospect of a loss of prestige or pay, staff may decide to look for other opportunities in the private sector or other organizations. Generally, it will be the staff with the highest potential that will be likely to leave. This problem may be particularly severe if banking supervision is to be transferred from the central bank and integrated into a new agency. The loss of highly qualified staff may severely impede the effectiveness of the supervisor.

There is also a risk that the change management process will go off track. The challenge of putting together several separate organizations is substantial and the managers in supervisory agencies seldom have experience with large-scale change management. Outside experts may need to be brought in and a detailed change-management plan needs to be developed and implemented if the integration process is to be relatively smooth.

Individual country cases suggest that creating an integrated supervisory agency can be a complex management challenge. For example, in Australia, the process of creating the integrated prudential supervision (APRA) was reviewed by Palmer (2002). The review noted that the integration was designed in an ambitious way and without a phase-in period, which had many potential benefits, likely to be realized in the medium to longer term. However, the review also notes a number of unavoidable short-term consequences, including: (i) some loss of corporate memory due to the departure of people from predecessor agencies; (ii) some loss of industry expertise, for the same reason; (iii) inevitable delays in reacquiring industry knowledge as new, less experienced people were recruited and asked to supervise more than one type of entity; and (iv) insufficient qualifications of some staff from predecessor agencies or newly recruited staff. According to Palmer (2002), these factors had a short-term negative impact on the quality of supervision.

Country cases suggest that integration should be implemented in a way that allows the key benefits to be reaped, namely (i) efficiency of transferring of information, experience and knowledge within the institution; (ii) harmonization of the quality of regulation and supervision, resulting in a better supervision of conglomerates; and (iii) cost savings resulting from the reduction in support activities. There are important risks in the integration process that need to be addressed, in particular: changing the existing "silo" culture; finding ways to address competing goals or possible conflicts of interest (monetary policy versus financial stability, prudential supervision versus consumer protection); accountability of results. Once the decision to move to an integrated agency has been made, implementation should take 
place quickly. A well-conceived change-management process should aim to overcome the cultural barriers associated with the previous structure.

Table 3. Summary of Pros and Cons of Integrating Financial Sector Supervision

\begin{tabular}{|l|l|}
\hline Potential Pros & Potential Cons \\
\hline $\begin{array}{l}\text { Easier to achieve efficiency in supervising financial } \\
\text { conglomerates. }\end{array}$ & $\begin{array}{l}\text { If objectives not clearly specified, may be less } \\
\text { effective than sectoral supervisors }\end{array}$ \\
\hline Possible economies of scale & $\begin{array}{l}\text { Possible diseconomies of scale if too large an } \\
\text { organization that is difficult to manage }\end{array}$ \\
\hline Possibly improved accountability & $\begin{array}{l}\text { If objectives not clearly communicated, possibility to } \\
\text { extend moral hazard problems across the whole } \\
\text { financial sector }\end{array}$ \\
\hline Easier to eliminate duplicities, turf wars & $\begin{array}{l}\text { Process of integration may lead to politically or } \\
\text { special interest motivated changes in supervisory } \\
\text { framework }\end{array}$ \\
\hline $\begin{array}{l}\text { Easier to ensure level playing field across market } \\
\text { segments }\end{array}$ & $\begin{array}{l}\text { Process of integration, if not managed properly, may } \\
\text { lead to loss of key staff or to other problems. }\end{array}$ \\
\hline
\end{tabular}

Source: Authors, based on the reviewed literature.

\section{Where Does the Central Bank Fit In?}

Another important issue is the degree to which the central bank should be involved in supervision. There is a general agreement that the central bank should be involved in macroprudential surveillance (see Table 1, left column). The degree of its involvement in microprudential supervision is an open question, both in the sectoral supervisor model (a number of central banks have been involved in banking supervision) and in the integrated supervisor model.

The arguments for and against the central bank being involved in banking supervision have been summarized by, for instance, Goodhart and Schoenmaker (1995). There are clearly some synergies between banking supervision and monetary policy. For instance, the central bank needs to be aware of the financial position of banks when formulating and implementing its monetary policy and there is a clear synergy between the information needed for banking supervision and the information about banks needed for monetary policy purposes. The central bank also needs to have information about the creditworthiness of the participants in the payment system, which involves an assessment of the solvency and risk management of individual banks, and information about the liquidity and solvency of banks for its lender of last resort responsibilities.

There are also operational arguments for the central bank being in charge of banking supervision. The economies of scale and commonalities between banking supervision and other functions of the central bank may be substantial and indeed stronger than those between banking and other parts of the financial sector. The overlap in expertise and experience required for banking supervision and other central banking functions may also allow the central bank to attract and retain the high quality staff. In some countries, the central bank has more independence and resources than any separate supervisor would likely have, so inclusion of banking supervision in the central bank protects bank supervision from political 
pressures and provides adequate resources - these are major pre-conditions for effective supervision.

However, the above issues can be largely resolved by appropriate legislation, funding, and cooperation among agencies and there are also arguments for separation of banking supervision and monetary policy. There may be conflict of interest between monetary and banking supervision goals, for instance, the central bank may not be sufficiently aggressive in controlling inflation when it fears that higher interest rates would lead to bank failures. Furthermore, bank failures happen and are often blamed on the supervisor. Then, if the credibility of the central bank as a bank supervisor is undermined, its credibility in monetary policy could suffer as well. Also, with new technology for the payment system (real time gross settlement systems), the central bank does not need to follow payment system participants as closely as was previously the case. As the financial system becomes more diversified and interconnected through financial conglomerates, the moral hazard arguments may be more important and it may be safer for the central bank to be separated from supervision and regulation.

Similar arguments apply for the question of whether the central bank should become the integrated supervisor. This solution may have practical advantages, particularly in countries where banking is the main form of intermediation and the non-bank financial sector is relatively small, where the central bank is independent and is in a better position to attract high caliber staff than other government agencies. However, there are also potentially strong disadvantages. First, the moral hazard issues are likely more serious if the central bank is to become the integrated supervisor, with the public expecting the same degree of protection for all institutions supervised by the central bank. Again, public education can alleviate but not solve this problem. Second, inevitable failures in the wide range of supervisory activities may have a negative impact on the credibility of the central bank in monetary policy. Third, there may be also concerns about the concentration of power in an independent, unelected body, particularly if there are no strong accountability mechanisms.

One additional consideration is the fundamental difference in the type of decisions taken by the central bank in monetary policy and decisions taken in supervision and regulation. This difference may put into question the ability of a single decision-making body to make both types of decisions effectively and efficiently. Here, the comparison between monetary policy and competition policy decisions put forward by Vickers (2002) appears to be relevant. Vickers notes that the monetary policy decision is basically the same decision taken repeatedly, simply defined (not simple!), and taken relatively transparently based on information that is largely publicly available. The effects of the decision are widespread, and there is no opportunity of appeal by those affected. Supervisory decisions are not taken at a predefined time, are based on private and often confidential information, there are many types of decisions that need to be made, concerned parties may be significantly affected, and have the opportunity to appeal the decision in court.

It remains unclear whether members of one decision making body would have sufficiently broad expertise and experience to be able to make qualified decisions on both monetary policy as well as a wide range of supervisory issues from banking to capital markets. If people with different experience are included in the decision making body, there is the 
danger that the decision making body will be split into monetary policy and supervisory parts, each one effectively making decisions in one area. Alternatively, if the decision making body would rely on staff or an advisory body, the clear lines of responsibility and accountability may become blurred. ${ }^{12}$

\section{E. Why Do Countries Integrate Their Supervisory Structures?}

In this section, we briefly review the evidence on how countries actually decide in practice. What makes country authorities decide for unified supervision? A few studies looked at the possible reasons for integration of supervision:

- $\quad$ Conglomeration. A number of studies (e.g., De Nicoló and others, 2003; IMF, 2004) mention the increased conglomeration of financial systems as a key reason for the decisions to integrate supervision. While cross-country data broadly support this view, there are a number of important exceptions. Some financial systems with complex conglomerates still apply the sectoral supervision model, while some relatively small systems dominated by banks have moved towards the integrated supervisor model.

- $\quad$ Central bank involvement. Freytag and Masciandro (2005), using econometric analysis, suggest that there is a trade-off between supervision unification and central bank involvement - the more the central bank is involved in financial supervisory powers, the lower the degree of concentration of those powers. Similarly, World Bank and IMF (2005) conclude that if a unified agency is created, it is more likely that the agency will be separate from the central bank

- $\quad$ Size of the economic systems. Freytag and Masciandro (2005) find that the lower the overall economic size (measured either by GDP or population), the higher the probability of integration. The small country effect captures the fact that with relatively few people the expertise in financial supervision is likely to be in short supply, and then this expertise might be more effectively utilized if it is concentrated within a single financial agency.

- $\quad$ Recent financial sector crisis. Case studies noted that in some cases, such as in the Nordics or Asia, the creation of integrated supervisors was prompted by a recent financial sector crisis (e.g., Carmichael, Fleming, and Llewellyn, 2004). A review of a broader sample of countries (Table 2) suggests, however, that the relationship is far from straightforward.

- Legal factors. Freytag and Masciandro (2005) suggest that countries with a "Civil Law root," meaning particularly the German and Scandinavian legal systems, have a higher probability of integrating their supervisory system.

\footnotetext{
${ }^{12}$ Some countries, e.g., Ireland, have tried to resolve this problem by integrating two separate boards within the central bank.
} 


\section{ANALYSIS OF INTERNATIONAL EXPERIENCE WITH INTEGRATED SUPERVISION}

In this section, we use available cross-country data on quality of supervision and on supervisory staffing to investigate whether integrated supervisory agencies have a higher and more even quality of supervision across sectors and whether they are more cost efficient than supervisors under other structures. This type of analysis has not yet been carried out in a systematic, cross-country fashion. There are only a few studies summarizing experience in individual country cases, e.g., Taylor and Fleming (1999), reviewing the early Northern European experience, and Carmichael, Fleming, and Llewellyn (2004).

\section{A. Does Integration Mean a Higher Quality of Supervision?}

Does integrated supervision mean that there is a higher quality of supervision? Or does integration mean diluting the higher quality of supervision in some sectors with a lower quality of supervision in other sectors? The theoretical literature is unclear on this point, only listing various pros and cons. In this subsection, we address this question empirically. We largely leave aside the more general issue whether and how better supervision translates into more sound financial systems, even though we offer some insights on this in Box 1.

To make the empirical analysis tractable, we focus on fully integrated supervisors. As mentioned in Section II, we define a fully integrated supervisory agency as an agency that is in charge of (micro)prudential supervision of at least the three main segments of most financial sectors - banking, insurance, and securities markets. We introduce an "integrated supervision dummy" that takes a value of 1 for economies with fully integrated supervision (see the list in Table 2) and 0 for all others. In principle, one can also distinguish partial integration, but we have not done it here, given that there are different types of such integration and their empirical comparison is far from straightforward.

We measure quality of supervision using the degree of compliance with internationally accepted standards in banking, insurance, and securities regulation. ${ }^{13}$ Those are, respectively, the Basel Core Principles for Effective Banking Supervision (BCP), the International Association of Insurance Supervisors (IAIS) Insurance Core Principles (ICP), and the International Association of Securities Commissions (IOSCO) Objectives and Principles of Securities Regulation (IOSCO). ${ }^{14}$ For example, the BCP contains 25 “Core Principles” (CPs) that include a wide range of issues, from the aims of supervision, autonomy, powers, and

\footnotetext{
${ }^{13}$ While this approach has some limitations — we need to assume that international standards measure the correct characteristics of the regulatory system and that the assessments are precise - and data is not available for all countries, we are not aware of any data set measuring the quality of regulation and supervision that would be more appropriate for our purposes.

${ }^{14}$ We focus on banks, insurance companies, and securities markets, given that these are the three main segments of most financial sectors, and considering that for these three groups there are corresponding international standards for supervision. Exclusion of other intermediaries from the analysis is likely to bias our results against integrated supervision, as integrated supervisors are more likely than sectoral supervisors to capture institutions that fall outside of these three main categories.
} 
resources (CP 1), through capital adequacy (CP 6), regulation of risks (CPs 11-13), to supervision of foreign banks (CP 25).

The methodology for assessing compliance with these standards and codes is well established, ${ }^{15}$ and an internal database of assessments based on assessment results has been created by the IMF. Most of the assessments have been prepared as part of the joint IMFWorld Bank assessment program, started in $1999 .{ }^{16}$ The compliance of each country with each core principle is assessed on a 4-point scale, from compliant to non-compliant, even though the exact names of the "grades" are slightly different across sectors.

We explore the relationship between observance of international standards and the organization of the supervisor (fully integrated or not) from two angles. First, we look at the $\mathrm{BCP}$, for which the highest number of assessments is available, construct an index of overall BCP compliance and explore relationships between this index and supervisory integration. Second, we look at all three standards in a consistent way, split the core principles in each area into four categories and, again, look for any relationship with supervisory integration.

For the BCP, we have a sample of 65 assessments mostly completed in 2000-2002, which includes a range of developing, emerging, and industrialized economies. ${ }^{17}$ We construct a simple index of overall BCP compliance by assigning values to assessment gradescompliant (4), largely compliant (3), materially non-compliant (2), and non-compliant (1). The value of the index of overall compliance for a given country is equal to the sum of ratings for individual core principles. ${ }^{18}$ Therefore, the actual values of the index of overall BCP compliance will be between 30 and 120, with higher values indicating a higher degree of compliance. ${ }^{19}$ Of the 65 countries in the sample, 12 countries had fully integrated supervisors at the time of the assessment.

A simple comparison of compliance in countries with integrated supervision and in other countries could be misleading as integrated supervisors tend to be found in more developed countries that also have a better general regulatory environment. There is a positive

\footnotetext{
${ }^{15}$ See $\underline{h t t p: / / w w w . i m f . o r g / e x t e r n a l / s t a n d a r d s / i n d e x . h t m ~ f o r ~ a ~ l i s t ~ a n d ~ f u r t h e r ~ d e t a i l s ~ o n ~ t h e ~ i n t e r n a t i o n a l l y ~}$ recognized standards and codes.

${ }^{16}$ Many countries have chosen to publish the summary of the financial sector assessments (Reports on Standards and Codes, or ROSCs). Some countries have chosen to publish also the detailed assessments, which include the underlying gradings of the individual principles. The published ROSCs and detailed assessments are available at the IMF and World Bank websites.

${ }^{17}$ The sample includes 13 advanced economies, 19 emerging market countries, and 33 developing countries; see Podpiera (2004) for the detailed list of countries.

${ }^{18}$ CPs that were "not assessed" or "not applicable" were assigned an average value of compliance of principles with available rating for a given country, so that these countries were not penalized.

${ }^{19}$ We treat the 6 subcategories of CP1 as separate principles. This does not have any significant impact on the index - the correlation coefficient of our index (with 6 subcategories treated as separate principles) and an index with only one entry for CP1 (equal to the average of the 6 subcategories) is 0.991 .
} 
relationship between the general regulatory environment on one hand and the level of implementation of standards on the other hand (see, for instance, IMF, 2004). We illustrate this problem in Figure 3, which shows the relationship between BCP compliance and the general regulatory environment as measured by one of the Kaufmann, Kraay, and Mastruzzi (KKM) (2003) indices. ${ }^{20}$ The upward-sloping regression line suggests a positive relationship between these two variables. However, Figure 3 also suggests that integrated supervisors generally have a higher degree of compliance with BCP even after taking the general regulatory environment into account -9 out of 12 integrated supervisors are above the regression line. To analyze this more formally, we now turn to regression analysis.

Figure 3. BCP Compliance and Overall Regulatory Environment

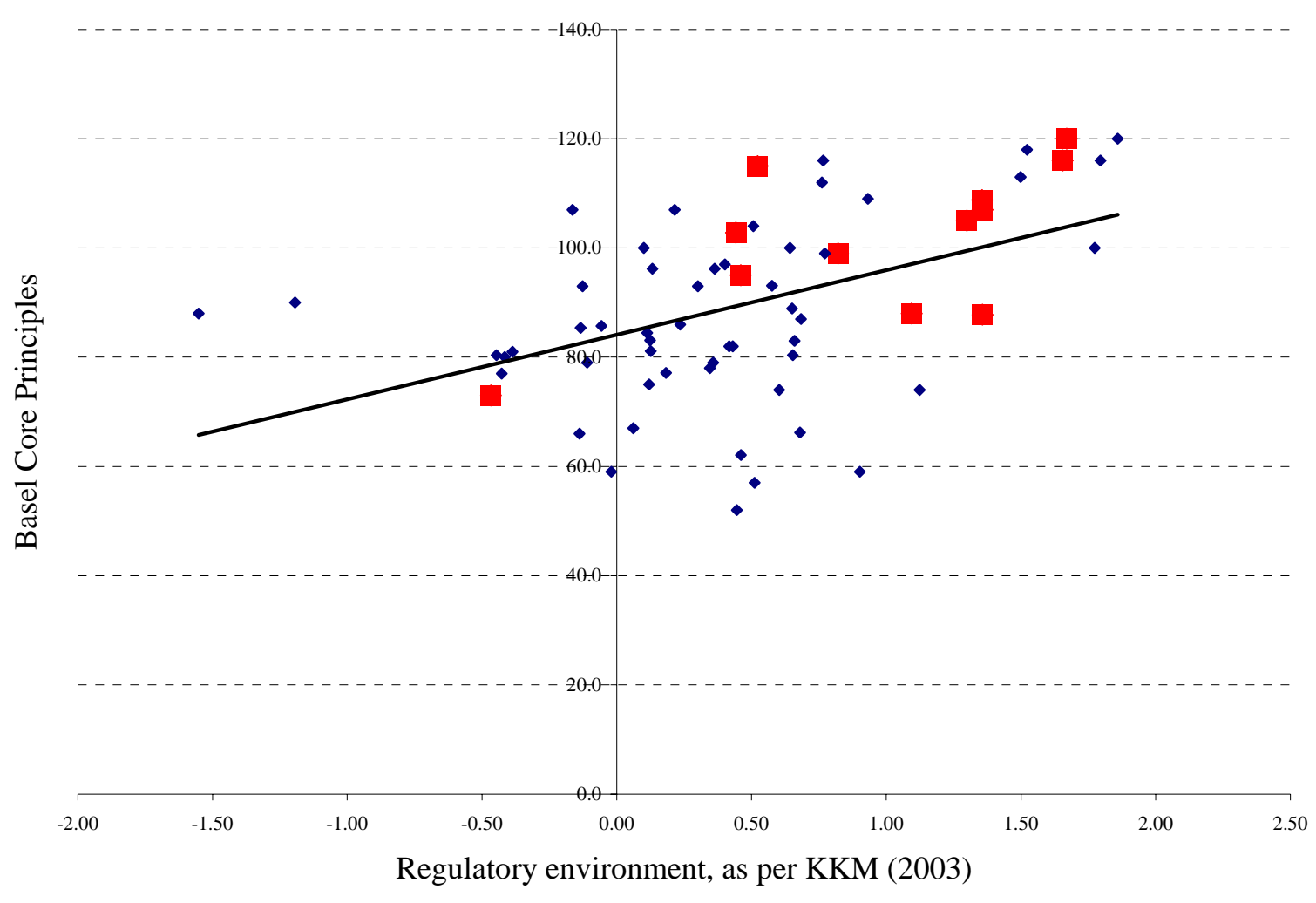

Notes: Large squares correspond to integrated regulators.

The regulatory environment index includes a measure of the incidence of market-unfriendly policies such as price controls or inadequate bank supervision, as well as perceptions of the burdens imposed by excessive regulation in areas such as foreign trade and business development.

Regression analysis confirms that fully integrated supervisory agencies tend to have a higher quality of banking supervision, but income level appears to be a more powerful explanatory

\footnotetext{
${ }^{20} \mathrm{KKM}$ (2003) describe regulatory quality as being focused on government policies and including measures of the incidence of market-unfriendly policies (e.g., controls or inadequate bank supervision), and perceptions of the burdens imposed by excessive regulation in areas such as foreign trade and business development.
} 
variable. The two key variables indicated in previous research is the quality of the general regulatory environment (KKM, 20003) and the GDP per capita (IMF, 2004). Table 4 presents four different specifications of a regression model, depending on whether we include one of the two variables, neither, or both.

In all the specifications, we distinguish integrated supervision by a dummy variable (1=fully integrated supervision; $0=$ other), and relevant the slope coefficient has a positive sign. If we include no other explanatory variable, the integrated regulator dummy is highly significant: the BCP compliance index in integrated supervisors is on average about 14 points higher than in other supervisory agencies. This difference shrinks to 8 points if we adjust for the higher overall quality of regulatory environment in countries with integrated supervision, and it shrinks further in half (and becomes insignificant) when we adjust for the higher GDP per capita in countries with integrated regulatory agencies. Regression (4) needs to be interpreted carefully, given that there is a positive correlation between the two explanatory variables, i.e., quality of regulatory environment and GDP per capita. ${ }^{21}$

Table 4. Explaining BCP Compliance

(Dependent variable: Index of BCP Compliance)

\begin{tabular}{|l|c|c|c|c|c|c|}
\hline $\begin{array}{l}\text { Model } \\
\text { Specification }\end{array}$ & Constant & $\begin{array}{c}\text { Integrated } \\
\text { Regulator } \\
\text { Dummy }\end{array}$ & $\begin{array}{c}\text { Quality of } \\
\text { Overall } \\
\text { Regulatory } \\
\text { Environment }\end{array}$ & $\begin{array}{c}\text { GDP Per } \\
\text { Capita (in } \\
\text { PPP, 2000) }\end{array}$ & $\begin{array}{c}\text { Number } \\
\text { of } \\
\text { Observations }\end{array}$ & R-Squared \\
\hline$(1)$ & $\begin{array}{c}87.16^{* * *} \\
(2.29)\end{array}$ & $\begin{array}{c}14.29 * * * \\
(4.56)\end{array}$ & $\ldots$ & $\ldots$ & 65 & 0.11 \\
\hline$(2)$ & $\begin{array}{c}83.37^{* * *} \\
(2.33)\end{array}$ & $\begin{array}{c}8.23^{*} \\
(4.44)\end{array}$ & $\begin{array}{c}10.23^{* * *} \\
(3.18)\end{array}$ & $\ldots$ & 65 & 0.26 \\
\hline$(3)$ & $\begin{array}{c}77.60^{* * *} \\
(2.42)\end{array}$ & $\begin{array}{c}4.67 \\
(4.69)\end{array}$ & $\ldots$ & $0.001^{* * *}$ & 65 & 0.45 \\
\hline$(4)$ & $\begin{array}{c}47.56 * * * \\
(2.48)\end{array}$ & $(4.87)$ & $\begin{array}{c}-0.75 \\
(2.68)\end{array}$ & $\begin{array}{c}0.001^{* * *} \\
(0.0002)\end{array}$ & 65 & 0.45 \\
\hline
\end{tabular}

Notes: */***** denotes significance level of 10/5/1 percent. Standard errors in parentheses. Ordinary least squares (OLS) estimation; the standard errors are heteroskedasticity-consistent. Index of BCP compliance is defined as the sum of gradings from 4 (compliant) to 1 (noncompliant) for individual CPs 2-25 and 6 sub-principles of CP1. Quality of the regulatory environment as per KKM (2003). It includes a measure of the incidence of market-unfriendly policies such as price controls or inadequate bank supervision, as well as perceptions of the burdens imposed by excessive regulation in areas such as foreign trade and business development. PPP denotes purchasing power parity.

Turning to the three sectors of banking, insurance, and securities markets, we use a sample of 36 countries for which assessments of compliance of all three sectors were prepared. ${ }^{22}$ As the

\footnotetext{
${ }^{21}$ We have also replaced the quality of regulatory environment with a KKM (2003) measure of "government effectiveness" which includes indicators of the quality of public service provision, the quality of the bureaucracy, the competence of civil servants, the independence of the civil service from political pressures, and the credibility of the government's commitment to policies. The results were very similar.

${ }^{22}$ This is the same sample used in IMF (2004) and consists of 10 industrialized countries, 12 emerging market countries, and 14 developing countries.
} 
core principles in these sectors are different, we need to transform the assessment results to be able to compare the quality of supervision across sectors. Following the methodology proposed in IMF (2004), we look at the following four main components of good regulation: (i) regulatory governance, which includes aims, independence, and accountability of regulators; (ii) prudential framework, i.e., risk management, capital adequacy, internal control, and corporate governance; (iii) regulatory practices, i.e., monitoring and supervision, enforcement, conglomerates, and licensing; and (iv) financial integrity/safety net, including consumer protection, and addressing financial crimes. For a listing of the core principles included in each of the four components, see Table 5.

For each of the four components, a compliance index was constructed, in a similar way as the BCP compliance index above, across countries and standards. The assessment of each principle was transformed into a numeric value from 4 (compliant) to 1 (noncompliant) and the compliance index was calculated as a simple average of the core principles included in a given component.

Table 5. Financial Standards and Their Four Main Components

\begin{tabular}{|c|c|c|c|c|}
\hline \multirow{2}{*}{$\begin{array}{l}\text { Four Main } \\
\text { Components }\end{array}$} & \multirow[t]{2}{*}{ Sub-components } & \multicolumn{3}{|c|}{ Sector (Core Principles) } \\
\hline & & $\begin{array}{l}\text { Banking } \\
\text { (BCP) }\end{array}$ & $\begin{array}{l}\text { Insurance } \\
\text { (ICP) } 1 /\end{array}$ & $\begin{array}{l}\text { Securities } \\
\text { (IOSCO) }\end{array}$ \\
\hline $\begin{array}{l}\text { Regulatory } \\
\text { Governance }\end{array}$ & $\begin{array}{l}\text { Objectives of regulation } \\
\text { Independence and adequate resources } \\
\text { Enforcement powers and capabilities } \\
\text { Clarity and transparency of regulatory process } \\
\text { External participation }\end{array}$ & 1,19 & 1 & $1,2,3,4,5,6,7$ \\
\hline $\begin{array}{l}\text { Prudential } \\
\text { Framework }\end{array}$ & $\begin{array}{l}\text { Risk management } \\
\text { Risk concentration } \\
\text { Capital requirements } \\
\text { Corporate governance } \\
\text { Internal controls }\end{array}$ & $\begin{array}{l}2,3,4,6,16,1 \\
7,18,20,22,2 \\
3,24,25\end{array}$ & $\begin{array}{l}2,3,4,5,12,1 \\
3,15,16,17\end{array}$ & $\begin{array}{l}8,9,10,11,12, \\
13,29 .\end{array}$ \\
\hline $\begin{array}{l}\text { Regulatory } \\
\text { Practices }\end{array}$ & $\begin{array}{l}\text { Group-wide supervision } \\
\text { Monitoring and on-site inspection } \\
\text { Reporting to supervisors } \\
\text { Enforcement } \\
\text { Cooperation and information sharing } \\
\text { Confidentiality } \\
\text { Licensing, ownership transfer, corporate control } \\
\text { Qualifications }\end{array}$ & $\begin{array}{l}5,6,7,8,9,10, \\
11,12,13,14\end{array}$ & $6,7,9,10$ & $\begin{array}{l}17,18,20,21 \\
22 \quad 23,25,27\end{array}$ \\
\hline $\begin{array}{l}\text { Financial } \\
\text { Integrity and } \\
\text { Safety Nets }\end{array}$ & $\begin{array}{l}\text { Markets (integrity, financial crime) } \\
\text { Customer protection } \\
\text { Information, disclosure, transparency. }\end{array}$ & 15,21 & 11,16 & $\begin{array}{l}14,15,16,19 \\
24,26,28 \\
30\end{array}$ \\
\hline
\end{tabular}

Source: IMF (2004).

$1 /$ The allocation of insurance principles are based on the 2000 IAIS standard.

Integrated supervisory agencies also tend to have higher quality of not only banking supervision, but also insurance supervision and securities regulation, measured by compliance with the relevant international standards (BCP, ICP, and IOSCO, respectively). 
The quality of supervision as measured by the four components is also correlated with the level of economic development, approximated by GDP per capita. ${ }^{23}$ The BCP results in Table 6 below are consistent with the more detailed BCP analysis presented earlier in Table 4, i.e., after an adjustment for the level of GDP per capita in countries with integrated supervisory agencies, we still find a positive point estimate of the integrated supervisor dummy, but these estimates are not statistically significant. On the other hand, for insurance (ICP) and securities (IOSCO), the integration dummy retains its statistical significance in some cases even after per capita income is taken into account. Namely, this is true for regulatory practices (insurance), prudential framework (securities), and financial integrity/safety net (both insurance and securities).

\section{Box 1. Integrated Supervision and Financial System Soundness}

Ideally, we would like to assess how supervisory integration helps in achieving the ultimate objective of prudential supervision, i.e., a stable and robust financial sector. However, understanding the links between quality of supervision (whether integrated or non-integrated) and financial sector performance is a very complex question that has not yet been properly addressed in the literature. We have therefore focused in this paper on the link between integration and quality of supervision, measured by compliance with international standards.

As regards financial soundness, let us just observe that countries with integrated supervision are obviously not absolutely immune to banking sector crises or other financial sector problems. A juxtaposition of the widelyaccepted list of systemic banking crises in Caprio and Klingebiel (2003) and the list of countries with integrated supervisory agencies does not suggest a lower frequency of systemic crises than in countries in general. In the 29 countries with integrated supervisory agencies, two cases of systemic banking crises were observed (Norway 1987-1993, Sweden, 1990-1993) and several episodes of important problems (even though not full-fledged banking crises) were observed in several other countries with integrated supervisors - for instance recent credit card problems in Korea or the $2001 \mathrm{HIH}$ collapse in Australia, see Palmer, 2002). It is early to assess whether the frequency of crises in countries with integrated supervisors is lower or higher than in other countries, but it is obvious that integrated supervision does not prevent crises completely.

Other proxies for the "ultimate output" of supervision include soundness indicators. Podpiera (2004) analyzed, using cross-country panel data, whether compliance with Basel Core Principles brings any measurable benefits, and found that higher levels of BCP compliance are accompanied by lower ratios of nonperforming loans to total loans, and lower margins. The existing data are not sufficient to perform a full-fledged econometric analysis. Nonetheless, as an introductory observation, the results presented in Table 4 would, in combination with results in Podpiera (2004), suggest that the presence of integrated supervision is likely to be associated with better soundness and performance indicators such as nonperforming loan ratios and interest rate margins. As with the other empirical analysis, however, causality remains an open question, i.e., is it that integration leads to better soundness indicators, or that systems with better soundness are more likely to have integrated supervision?

\footnotetext{
${ }^{23}$ As for the BCP estimation above, we have also included variables measuring the quality of regulatory environment and government effectiveness, but they were not significant in almost all specifications, when GDP per capital was also included.
} 
Table 6. Explaining BCP, ICP and IOSCO Compliance by Main Components

(Dependent variables: Indices of BCP, ICP, and IOSCO compliance, respectively)

\begin{tabular}{|c|c|c|c|c|c|}
\hline & Constant & $\begin{array}{l}\text { Integrated } \\
\text { Regulator } \\
\text { Dummy }\end{array}$ & $\begin{array}{l}\text { GDP Per Capita } \\
\text { (PPP) }\end{array}$ & $\begin{array}{l}\text { Number of } \\
\text { Observations }\end{array}$ & R-Squared \\
\hline \multicolumn{6}{|l|}{$\begin{array}{l}\text { Banking } \\
\text { (BCP) }\end{array}$} \\
\hline $\begin{array}{l}\text { Regulatory } \\
\text { governance }\end{array}$ & $\begin{array}{c}3.02^{* * *} \\
(0.11)\end{array}$ & $\begin{array}{c}0.02 \\
(0.16) \\
\end{array}$ & $\begin{array}{c}2.08^{* * *} \\
(0.53)\end{array}$ & 36 & 0.25 \\
\hline $\begin{array}{l}\text { Prudential } \\
\text { framework }\end{array}$ & $\begin{array}{c}2.92^{* * *} \\
(0.10)\end{array}$ & $\begin{array}{c}0.08 \\
(0.15)\end{array}$ & $\begin{array}{c}2.17^{* * *} \\
(0.53)\end{array}$ & 36 & 0.38 \\
\hline $\begin{array}{l}\text { Regulatory } \\
\text { practices }\end{array}$ & $\begin{array}{c}2.62 * * * \\
(0.13)\end{array}$ & $\begin{array}{c}0.13 \\
(0.19)\end{array}$ & $\begin{array}{c}2.81^{* * *} \\
(0.72)\end{array}$ & 36 & 0.36 \\
\hline $\begin{array}{l}\text { Financial } \\
\text { integrity/safety net }\end{array}$ & $\begin{array}{c}2.50^{* * *} \\
(0.20)\end{array}$ & $\begin{array}{c}0.06 \\
(0.23) \\
\end{array}$ & $\begin{array}{l}3.89 * * * \\
(1.25)\end{array}$ & 36 & 0.38 \\
\hline \multicolumn{6}{|l|}{$\begin{array}{l}\text { Insurance } \\
\text { (ICP) }\end{array}$} \\
\hline $\begin{array}{l}\text { Regulatory } \\
\text { governance }\end{array}$ & $\begin{array}{c}2.36 * * * \\
(0.22)\end{array}$ & $\begin{array}{c}0.23 \\
(0.26)\end{array}$ & $\begin{array}{c}2.38^{* * *} \\
(0.85)\end{array}$ & 34 & 0.18 \\
\hline $\begin{array}{l}\text { Prudential } \\
\text { framework }\end{array}$ & $\begin{array}{c}2.93^{* * *} \\
(0.11)\end{array}$ & $\begin{array}{c}0.15 \\
(0.14)\end{array}$ & $\begin{array}{c}1.92^{* * *} \\
(0.52)\end{array}$ & 36 & 0.31 \\
\hline $\begin{array}{l}\text { Regulatory } \\
\text { practices }\end{array}$ & $\begin{array}{c}2.51^{* * *} \\
(0.16) \\
\end{array}$ & $\begin{array}{l}0.36 * * \\
(0.14) \\
\end{array}$ & $\begin{array}{c}2.40^{* * *} \\
(0.50)\end{array}$ & 36 & 0.37 \\
\hline $\begin{array}{l}\text { Financial } \\
\text { integrity/safety net }\end{array}$ & $\begin{array}{c}2.32 * * * \\
(0.21)\end{array}$ & $\begin{array}{l}0.42^{*} \\
(0.21)\end{array}$ & $\begin{array}{c}3.21^{* * *} \\
(0.90)\end{array}$ & 36 & 0.35 \\
\hline \multicolumn{6}{|l|}{$\begin{array}{l}\text { Capital markets } \\
\text { (IOSCO) }\end{array}$} \\
\hline $\begin{array}{l}\text { Regulatory } \\
\text { governance }\end{array}$ & $\begin{array}{c}2.90 * * * \\
(0.16)\end{array}$ & $\begin{array}{c}0.11 \\
(0.20)\end{array}$ & $\begin{array}{l}2.03^{* *} \\
(0.75)\end{array}$ & 36 & 0.20 \\
\hline $\begin{array}{l}\text { Prudential } \\
\text { framework }\end{array}$ & $\begin{array}{c}2.45^{* * * *} \\
(0.14)\end{array}$ & $\begin{array}{l}0.42^{*} \\
(0.23)\end{array}$ & $\begin{array}{c}2.96^{* * *} \\
(0.70)\end{array}$ & 36 & 0.41 \\
\hline $\begin{array}{l}\text { Regulatory } \\
\text { practices }\end{array}$ & $\begin{array}{c}2.94 * * * \\
(0.17)\end{array}$ & $\begin{array}{c}0.14 \\
(0.18)\end{array}$ & $\begin{array}{c}2.22^{* * *} \\
(0.62)\end{array}$ & 36 & 0.21 \\
\hline $\begin{array}{l}\text { Financial } \\
\text { integrity/safety net }\end{array}$ & $\begin{array}{c}2.52^{* * *} \\
(0.13)\end{array}$ & $\begin{array}{l}0.34^{*} \\
(0.19)\end{array}$ & $\begin{array}{c}2.89 * * * \\
(0.13)\end{array}$ & 36 & 0.42 \\
\hline
\end{tabular}

Notes: */**/*** denotes significance level of 10/5/1 percent. Standard errors in parentheses.

Ordinary least squares (OLS) estimation; the standard errors are heteroskedasticity-consistent.

The indices of BCP, ICP, and IOSCO compliance were calculated as a simple average of the core principles included in a given component, please see the discussion in the text above. We have also included variables measuring the quality of regulatory environment and government effectiveness, but they were not significant in almost all specifications, when GDP per capital was also included. PPP denotes purchasing power parity.

Whether the integrated supervision is located inside or outside the central bank does not have a significant impact on the quality of supervision. We have tried to distinguish, in the regressions in Table 4 and Table 6, integrated regulators in central banks from those outside central banks, but the estimated coefficients were generally not significant.

The regression results need to be interpreted with caution. In particular, the estimations do not look at causality and should not be interpreted in a causal way. The estimates do not make it possible to determine whether integration leads to higher quality of supervision, or 
whether supervisory agencies with a higher quality of supervision are more likely to get integrated.

\section{B. Does Integration Mean More Consistent Supervision Across Sectors?}

More consistent regulation and supervision across sectors is one of the important suggested advantages of integrated supervision. The data on the four components of the BCP, ICP, and IOSCO standards described above-regulatory governance, prudential framework, regulatory practices, and financial integrity/safety net—allow us to test whether integrated supervisors achieve more consistent quality of regulation across the three financial sectors. For each of the four components, we use the variation coefficient (standard deviation/average) across the three sectors as a measure of consistency. Again, as one would expect more developed countries to have a more consistent regulatory framework for the whole financial sector, we include GDP per capita (in purchasing power parity, PPP) as a control variable.

Our results suggest that integrated supervisory agencies indeed tend to have a more consistent quality of supervision across the sectors they supervise (Table 7). We have found that integrated supervisors have lower variation coefficient of the degree of compliance with international standards and the impact of integration seems to be higher in the area of regulatory practices and financial integrity/safety net and generally holds even after the level of development of an economy (GDP per capita in PPP) is taken into account.

Table 7. Explaining Variability in Compliance with International Standards Dependent variable: Variation Coefficient (standard deviation/average) of an index of compliance with international standards on supervision in banking, insurance, and securities markets

\begin{tabular}{|c|c|c|c|c|c|}
\hline & Constant & $\begin{array}{l}\text { Integrated } \\
\text { Regulator } \\
\text { Dummy } \\
\end{array}$ & $\begin{array}{c}\text { GDP Per } \\
\text { Capita (in PPP) } \\
1 / \\
\end{array}$ & $\begin{array}{c}\text { Number of } \\
\text { Observations }\end{array}$ & R-squared \\
\hline $\begin{array}{l}\text { Regulatory } \\
\text { governance }\end{array}$ & $\begin{array}{r}0.25 * * * \\
(0.03)\end{array}$ & $\begin{array}{r}-0.04 \\
(0.03)\end{array}$ & $\begin{array}{r}-0.37 * * * \\
(0.12)\end{array}$ & 36 & 0.20 \\
\hline $\begin{array}{l}\text { Prudential } \\
\text { framework }\end{array}$ & $\begin{array}{r}0.18 * * * \\
(0.01)\end{array}$ & $\begin{array}{r}-0.04 \\
(0.03) \\
\end{array}$ & $\begin{array}{r}-0.28 * * * \\
(0.10) \\
\end{array}$ & 36 & 0.30 \\
\hline $\begin{array}{l}\text { Regulatory } \\
\text { practices }\end{array}$ & $\begin{array}{r}0.21 * * * \\
(0.02)\end{array}$ & $\begin{array}{l}-0.05^{*} \\
(0.02)\end{array}$ & $\begin{array}{r}-0.31^{* * * *} \\
(0.08)\end{array}$ & 36 & 0.42 \\
\hline $\begin{array}{l}\text { Financial } \\
\text { integrity/safety net }\end{array}$ & $\begin{array}{r}0.22 * * * \\
(0.03)\end{array}$ & $\begin{array}{l}-0.06^{*} \\
(0.03)\end{array}$ & $\begin{array}{r}-0.24 \\
(0.15)\end{array}$ & 36 & 0.17 \\
\hline Overall & $\begin{array}{r}0.15 * * * \\
(0.02)\end{array}$ & $\begin{array}{r}-0.04 * * * \\
(0.02)\end{array}$ & $\begin{array}{r}-0.17 * * * \\
(0.08)\end{array}$ & 36 & 0.24 \\
\hline
\end{tabular}

Notes: */**/*** denotes significance level of 10/5/1 percent. Standard errors in parentheses.

Ordinary least squares (OLS) estimation; the standard errors are heteroskedasticity-consistent. PPP denotes purchasing power parity.

1/ Coefficients multiplied by $10^{5}$.

\section{Does Integration Help Reduce Resource Costs?}

One of the arguments in favor of integrated supervision is the possibility that integration may lower costs, both for supervisors and for the supervised institutions. Data that would allow us to analyze changes in regulatory burden are scant at best. We therefore focus on supervisory 
staff resources, for which cross-country data are available in the annual report, How Countries Supervise Their Banks, Insurers, and Securities Markets, published by Central Banking Publications (the latest edition available to us was 2004). As far as we know, the data have not yet been used for this type of analysis.

We find that integrating supervision does not lead to substantial supervisory staff reduction (Table 8). We have tried to explain the number of supervisory staff by country population, area, the level of development (approximated by GDP per capita), and the size of the financial sector (approximated by M2/GDP). We have found that population matters, as does the country's level of development. The dummy variable for integrated regulators has the expected negative sign, but the reduction in staffing associated with supervisory integration was not statistically significant. That may be for several reasons. First, the time since integration has in most cases not yet been sufficient for the cost savings to materialize. Second, we look at supervisory staff numbers, not at total staff numbers, so there could be some savings in support staff that we do not observe. Third, there may be no savings in supervisory staff because in some cases the integrated regulator took on new responsibilities that the previous regulators did not have (e.g., supervision of additional types of financial firms, or functions previously not covered, such as consumer protection) or, fourth, there may not be any true synergies among the sectors that would allow for supervisory staff savings.

In addition to this cross-country analysis, we have also looked at changes in supervisory staffing over time in countries that introduced integrated supervision, compared to other countries. The cross-country supervisory staffing data are available only for 1996-2003 [Central Banking Publications (1999-2004)], which limits the time dimension of our analysis. We have therefore focused on supervisory agencies that were integrated during 1998-2002, and compared the total staffing of all the supervisory agencies in the country at the end of 1996 with the staffing of the integrated agency at the end of 2003. Similarly to the cross sectional analysis, we have found no evidence of a systematic reduction in supervisory staffing, even though there were individual country cases when such reduction took place (Figure 4). On average, supervisory staffing in the 61 countries for which we had observations increased by 23 percent between 1996 and 2003. For the sub-sample of 14 countries that underwent integration of supervisory agencies between 1998 and 2002, supervisory staffing also increased in the same period; this increase was smaller on average (16 percent), but this difference was not significant (the standard deviation of the changes was 27 percent). Countries with supervisory agencies integrated before 1998 recorded an above average increase in staffing in the same period (by 41 percent, with standard deviation of 26 percent). These findings are in line with the results of the cross country analysis presented in Table 7. In particular, they suggest that integration of supervisory agencies is not associated with substantial reductions in supervisory staff. 
Table 8. Integrated Supervision and Staffing

Dependent variable: Total Number of Professional Supervisory Staff

\begin{tabular}{|c|c|c|c|c|c|c|c|c|}
\hline Model & Constant & $\begin{array}{c}\text { Integrated } \\
\text { Regulator } \\
\text { Dummy }\end{array}$ & $\begin{array}{c}\text { Population } \\
1 /\end{array}$ & $\begin{array}{c}\text { GDP Per } \\
\text { Capita } \\
\text { (PPP) 1/ }\end{array}$ & $\begin{array}{c}\text { Area } \\
1 /\end{array}$ & M2/GDP & $\begin{array}{c}\text { Number of } \\
\text { Observations }\end{array}$ & R-Squared \\
\hline$(1)$ & $-999^{*}$ & -69.6 & $238^{* * *}$ & 96.4 & 10.3 & 2.21 & 55 & 0.49 \\
$(127)$ & $(55.9)$ & $(70.9)$ & $(48.6)$ & $(2.63)$ & & \\
\hline$(2)$ & $-1,018^{*}$ & -102 & $244^{* * *}$ & $\begin{array}{c}123^{* *} \\
(56.0)\end{array}$ & $\begin{array}{c}-6.92 \\
(36.7)\end{array}$ & $\cdots$ & 58 & 0.47 \\
\hline$(3)$ & $-1,063^{* *}$ & -108 & $236^{* * *}$ & $127^{* *}$ & $\cdots$ & $\cdots$ & 58 & 0.47 \\
& $(450)$ & $(121)$ & $(38.5)$ & $(48.3)$ & & & & \\
\hline$(4)$ & $-442^{* * *}$ & -70.5 & $\ldots$ & $\cdots$ & $\cdots$ & $\cdots$ & 64 & 0.003 \\
\hline
\end{tabular}

Note: Standard errors in parentheses. */**/*** denotes significance level of 10/5/1 percent. PPP denotes purchasing power parity.

1/ Logarithm.

Figure 4. Supervisory Staffing in Countries with Integrated Supervision, 1996-2003

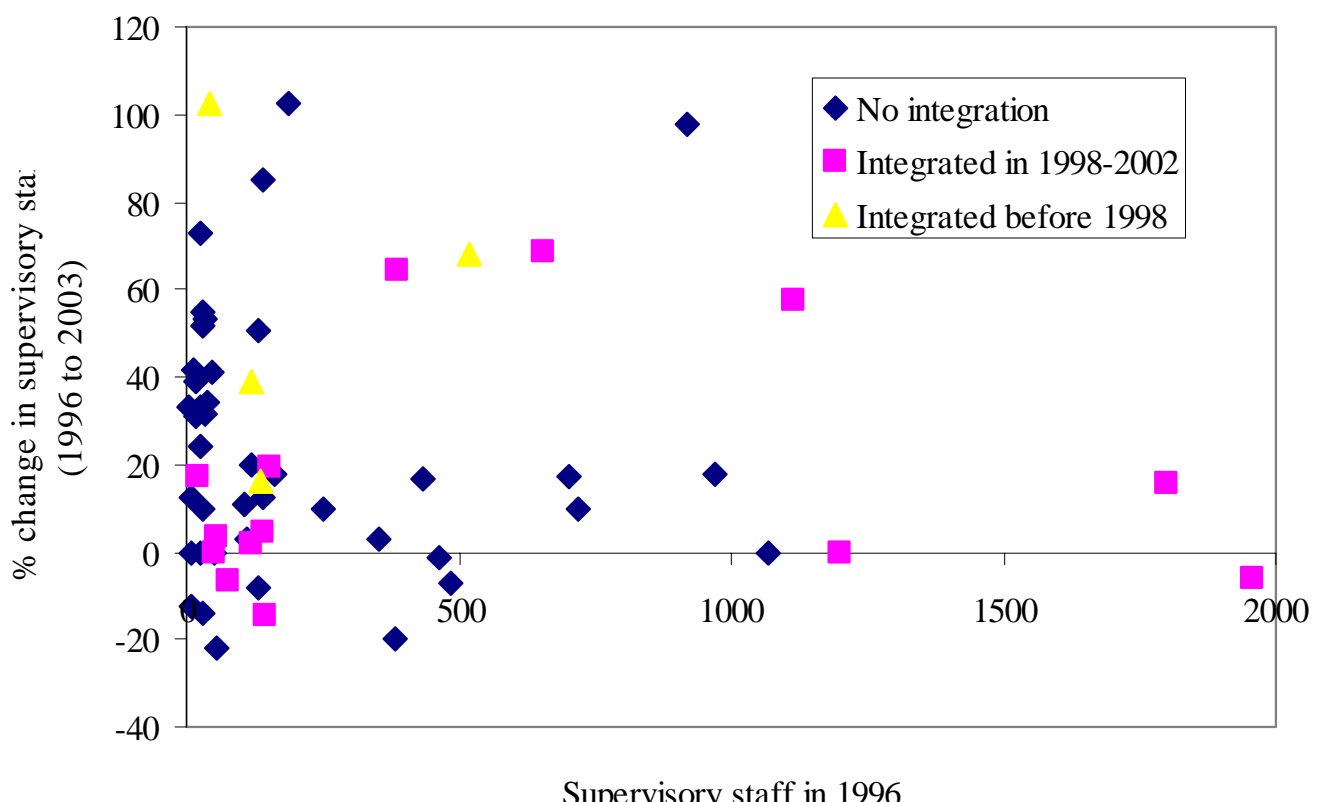

Source: Authors’ calculations, based on data from Central Banking Publications (1999-2004).

\section{CONCLUSiOnS}

The theoretical literature on integrated supervision is relatively inconclusive. The prevalent view among the observers is that there is no optimal supervisory structure (Camichael, Fleming, and Llewellyn, 2004), but that there are various pros and cons that need to be taken into consideration in individual country cases. 
Our empirical results suggest several preliminary conclusions:

- We found that countries with integrated supervisory agencies enjoy greater consistency in quality of supervision across supervised institutions, even though a part of the difference is due to the higher level of development in countries with integrated supervisory agencies.

- $\quad$ This greater consistency is not associated with diluting the overall quality of supervision; on the contrary, we find that integrated supervision is associated with a higher overall quality of supervision. For banking, the higher quality can be explained by an above-average level of economic development in the countries that have so far opted for integrated supervision. For insurance and securities markets, the higher level cannot be fully explained by economic level, suggesting that other factors, notably integration of supervision may be at play. Overall, these results may be interpreted as suggesting that integration, while not having an impact on banking regulation, is associated with a higher quality of regulation in other sectors and, thus, greater consistency and overall quality of regulation.

- Whether the integrated supervision is located inside or outside the central bank does not appear to have a significant impact on the quality of supervision.

- Integrating supervision does not seem to be associated with significant reduction of supervisory staff. That may be either because the time since integration has, in most cases, not yet been sufficient for the cost savings to materialize or because there are no cost savings (e.g., because the integrated supervisors took on new responsibilities). It is also possible that there are savings in support staff and support activities, but cross-country data on those are not available.

The preliminary conclusions in this paper suggest that integrated supervision may be associated with substantial benefits, particularly in terms of increased supervisory consistency and quality. This strengthens the case in favor of integrated supervision in the medium-to-long term. Country authorities considering whether to integrate their supervisory framework need to compare the likely medium- and long-term benefits (in particular, of having a single institution with the potential for better information flows and more consistent supervisory practices, better supervision of conglomerates, and possible cost savings on support activities) with the short-term challenges and risks involved in the integration process and in the chosen model.

There are a number of topics to follow up on in further research, in particular:

- $\quad$ Degree of integration. The presented paper compared fully integrated supervisory agencies with all others. This "zero-one” approach made the analysis more straightforward, but abstracted from the fact that there is a continuum of degrees of integration. In future research, one could investigate whether creating partially integrated supervisors is an improvement over the purely sectoral model. The key challenge in this approach is how to define, in an objective and cross-country comparable way, the many different degrees of supervisory integration. Also, some 
nonintegrated supervisory agencies may have in place a good framework for cooperation, while some supervisory agencies may be integrated only on paper.

Moreover, in some countries, there is an integrated prudential regulator, but a small part of the responsibilities is for practical reasons carried out by a cooperating agency. These factors are likely to play a role, but are much more difficult to model. Therefore, we have used the zero-one approach in this paper, but including a more continuous definition of integration is a challenge for future research.

- $\quad$ Burden on financial institutions. An important argument in favor of integrated supervision is that it helps reduce the regulatory burden. Only limited data are presently available to address this question. Those data suggest that integration indeed leads to some reduction in regulatory overlaps and duplications. If more complete data become available, a more rigorous analysis on this issue can be carried out, most likely strengthening the arguments for integrated supervision.

- $\quad$ Cross-border integration. Recent policy papers on supervision have devoted substantial attention to the modalities of home-host supervisory cooperation (e.g., Basel Committee on Banking Supervision, 2005). However, in terms of empirical research, this subject has received even less attention than domestic supervisory integration.

- $\quad$ Formal models. There is also scope for developing formal theoretical models of integrated supervision. At present, the theoretical literature consists of formal models focusing on banking supervision (e.g., Dewatripont and Tirole, 1994), and various lists of pros and cons not based on an explicit model.

- $\quad$ Supervision of conglomerates. Given that a greater importance of conglomerates has been one of the key stated reasons for integration, it would be useful to explore directly whether integrated supervisors are more successful in creating and implementing a consistent and complete framework for the supervision of conglomerates. The methodology used in the empirical section of this paper addresses the issue, but only using indirect methods. 


\section{REFERENCES}

Abrams, Richard K, and Michael W. Taylor, 2000, "Issues in the Unification of Financial Sector Supervision,” IMF Working Paper 00/213 (Washington: International Monetary Fund).

Basel Committee on Banking Supervision, 2005, "Home-host information sharing for effective Basel II implementation” (Basel: Bank for International Settlements). http://www.bis.org/publ/bcbs120.htm

Caprio Jr., Gerard, and Daniela Klingebiel, 2003, Banking Crises Database (Washington D.C.: World Bank). http://www1.worldbank.org/finance/html/database sfd.html

Carmichael, Jeffrey, Alexander Fleming, and David T. Llewellyn, 2004, Aligning Financial Supervisory Structures with Country Needs (Washington, DC: World Bank).

Central Banking Publications, 1999-2004, How Countries Supervise their Banks, Insurers, and Securities Markets (London: Central Banking Publications). Annual reports.

Das, Udaibir S., and Marc Quintyn, 2002, “Crisis Prevention and Crisis Management: The Role of Regulatory Governance,” IMF Working Paper 02/163 (Washington: International Monetary Fund).

Das, Udaibir S., Marc Quintyn, and Kina Chenard, 2004, “Does Regulatory Governance Matter for Financial System Stability? An Empirical Analysis.” IMF Working Paper 04/89 (Washington, DC: International Monetary Fund).

De Nicoló, Gianni, Philip F. Bartholomew, Jahanara Zaman, and M. G. Zephirin, 2003, "Bank Consolidation, Internationalization and Conglomeration: Trends and Implications for Financial Risk,” IMF Working Paper 03/158 (Washington: International Monetary Fund).

Dewatripont, M., and Jean Tirole, 1994, The Prudential Regulation of Banks (Cambridge, Massachusetts: MIT Press).

Freytag, Andreas, and Donato Masciandro, 2005, "Financial Supervision Unification and Central Bank Fragmentation Effect," Quaderni del Dipartimento di Scienze Economiche dell'Università di Lecce - Collana di Economia; 74/35; pp. 15-24.

Goodhart, C. A. E., and D. Schoenmaker, 1995, "Institutional Separation between Supervisory and Monetary Agencies,” in The Central Bank and the Financial System ed. by C. A. E. Goodhart (Cambridge, Massachusetts: MIT Press).

Group of Ten, 2001, “Consolidation in the Financial Sector” (Basel). 
Holthausen, Cornelia, and Thomas Rønde, 2004, "Cooperation in International Banking Supervision” Centre for Industrial Economics Discussion Papers 2004-02 (Copenhagen: University of Copenhagen), available on the web at http://www.econ.ku.dk/CIE/Discussion\%20Papers/2004/2004-02.pdf.

Huepkes Eva, Marc Quintyn, and Michael W. Taylor, 2005, “The Accountability of Financial Sector Supervisors: Principles and Practice,” IMF Working Paper 05/51 (Washington: International Monetary Fund).

International Monetary Fund (IMF), 2004, Financial Sector Regulation: Issues and Gaps. (Washington: International Monetary Fund), available on the web at http://www.imf.org/external/np/mfd/2004/eng/080404.pdf.

Kahn, Charles M., and João A.C. Santos, 2005, “Allocating Bank Regulatory Powers: Lender of Last Resort, Deposit Insurance and Supervision,” European Economic Review, Vol. 49, pp. 2107-36.

Kaufmann, Daniel, Aart Kraay, and Massimo Mastruzzi (KKM), 2003, “Governance Matters III: Governance Indicators for 1996-2002” (Washington: World Bank), available on the web at www.worldbank.org.

Kremers, Jeroen J.M., Dirk Schoenmaker, and Peter J. Wierts, 2001, “Does Europe Need a Euro-Wide Supervisor?” The Financial Regulator; 6, No. 3, pp. 50-56. , 2003, “Cross-Sector Supervision: Which Model?” Brookings-Wharton Papers on Financial Services, pp. 225-243

Oosterloo, Sander, and Jakob de Haan, 2003, “A Survey of International Frameworks for Financial Stability.” Occasional Studies, Vol. 1, No. 4 (Amsterdam: De Nederlandsche Bank).

Palmer, John, 2002, "Review of the Role Played by the Australian Prudential Regulation Authority and the Insurance and Superannuation Commission in the Collapse of the HIH Group of Companies,” July 15, 2002, available on the web at www.apra.gov.au.

Podpiera, Richard, 2004, "Does Compliance with Basel Core Principles Bring Any Measurable Benefits?” IMF Working Paper 04/204. (Washington: International Monetary Fund).

Reserve Bank of New Zealand, 2005, Financial Stability Report, May, available on the web at http://www.rbnz.govt.nz/finstab/fsreport/fsr may2005.pdf.

Taylor, Michael, and Alexander E. Fleming, 1999, "Integrated Financial Supervision: Lessons from Northern European Experience,” Policy Research Working Paper 2223. (Washington: World Bank). 
Vickers, John, 2002, “The Hedgehog and the Fox in Economic Policy,” Oxford Business Alumni Lecture, June 2002, available on the web at http://www.oft.gov.uk/NR/rdonlyres/932DC0F2-6E41-436A-A4FFA21E894A543F/0/spe0502.pdf.

World Bank and the International Monetary Fund, 2005, Financial Sector Assessment: A Handbook (Washington: World Bank and the IMF), available on the web at http://www.imf.org/external/pubs/ft/fsa/eng/index.htm.

Zalm, Gerrit, 2005, “Blurring of Distinctions: The Policy Response,” Speech for the conference: Integrated Supervision of Financial Conglomerates: Challenges for the Future, May 12 (Amsterdam, De Nederlandsche Bank). 